\title{
The Effects of Digitalization on Customer Experience
}

\author{
Gábor Rekettye \\ University of Pécs, Hungary \\ Gábor Rekettye, Jr. \\ International Business School, Budapest, Hungary
}

\section{Abstract}

Digitalization is the core driving force of the fourth industrial revolution. This new era will result in paradigm shift in production and in marketing of products and services. The smarter production can make value creation easier with reducing the cost of manufacturing and with producing better quality. It will enable a more customized even personalized production. The digitalization driven paradigm shift will make it possible to personalize also the marketing tools, like pricing, distribution, communication, customer management, and customer experience, which embraces all interaction between the seller and the customers. The aim of this conceptual study is to discuss the definition and role of customer experience (CX) in the today's digital world and draw the attention to this issue in the Central and EasterEuropean countries where CX theory and practice seems to be lagging behind the Western countries. To exploit the new possibilities of customer experience companies must understand how the customer decision journey has changed and they have to map and explore those new touchpoints, which determine customers' purchasing decisions. The issue of the new methods of customer experience brings up also new ethical questions, like the contradiction between the data need of personalization about customers, and the need to prevent their privacy against intruding. This "catch 22" will also be discussed in the study.

Keywords: digitalization, customer experience, personalization, customer decision journey, touchpoints, ethical questions

JEL classification: M11, M20, M21, O14

\section{Introduction}

There is a unanimous consort among scientists that in the first decades of the twenty first century the world is moving towards a new industrial revolution called Industry 4.0. (Schwab, 2017; Liao at al., 2017; Vaidya et al., 2018). There is also a common understanding that digitalization is the core driving force of the fourth industrial revolution. The fourth industrial revolution was also the leading topic at the World Economic Forum in Davos, 2016 with the title: Mastering the Fourth Industrial Revolution. The forum discussed both the positive and the negative aspects of the fourth industrial revolution. As Schwab put it: „There has never been a time of greater promise, or peril". Studying the relevant international literature, we may conclude that according to the scientists the fourth industrial revolution will fundamentally transform the global system of production, which means a paradigm shift in manufacturing. (Moavenzadeh, 2015; Baur and Wee, 2015; Geissbaver et al., 2016). The cyberphysical system of the new production will result in radical cost reduction, in better 
quality, in faster time to market and in more customized - even personalized production.

Less attention is devoted in literature however to the marketing effects of the fourth industrial revolution. This study concludes that the tools of the fourth industrial revolution, especially the analytics of big data and its rational use may lead to a paradigm shift in marketing as well. The real time availability of information about the customers will give sellers the possibility to personalize not only the products and services but also the other means of the marketing mix: distribution, pricing, and communications (Rekettye and Rekettye Jr., 2019). Because all of this development, the role of customer experience will be increasingly important. Customer experience is a relatively new field of modern marketing, and its use is continuously changing and getting more sophisticated due to the advanced digitalization.

The aim of this conceptual study is to discuss the definition and role of customer experience in the today's digital world and draw the attention to this issue in the Central and Easter-European countries where CX theory and practice seems to be lagging behind the Western countries.

\section{The Notion and the Role of Customer Experience}

Numerous studies have been published about customer experience (CX) in marketing literature over the past decade. The common view is that successful companies apply an additional layer to the quality representing the essence of their products and to the attractiveness of the appearance thereof; and this additional layer is none other than customer experience, positive customer experience (Rekettye, 2018).

Market research reports prove that the importance of the role of customer experience has increased from the perspective of customers as well as the sellers of both consumer and industrial goods.

A Salesforce's research (2018) made on a sample of around 7000 consumers and business byers in the advanced countries states for example that

- $80 \%$ of customers say the experience a company provides is as important as its products/services;

- $67 \%$ of customers are willing to pay more for a great experience;

- $57 \%$ of the customers have stopped buying from a company because a competitor provided a better experience.

According to Acquia (2018) research

- $76 \%$ of consumers say 'I am loyal to certain brands, but as soon as I have a bad experience with them, I am moving on'

According to NICE in Contact (2018) research

- $89 \%$ of consumers are willing to buy more and

- $82 \%$ are willing to go out of their way to buy from companies that deliver exceptional customer experience.

Nevertheless, what does customer experience really mean? It is not easy to define. As Adam Richardson (2010), the author of the first part of the series of articles on customer experience published in the Harvard Business Review writes "people have been grappling with a definition of customer experience for several years. Sometimes it's defined as digital experiences and interactions, such as on a website or a smartphone. In other cases, customer experience is focused on retail or customer service, or the speed at which problems are solved in a call center". According to him, customer experience is the "sum-totality of the emotions built up in the customer with regard to the brand and the company throughout the entire arc of being a customer." 
Lemon and Verhoef (2016) studying the vast literature of CX concluded that CX is a multidimensional construct that has rational, emotional, sensorial, and social factors. "However, an experience may relate to specific aspects of the offering, such as a brand or technology, and it consists of individual contacts between the firm and the customer at distinct points. An experience is built up through a collection of these touchpoints in multiple phases of customer decision process or purchase journey". (Lemon and Verhoef, 2016, p. 71).

Looking at this definition, we can realize that most of the customer experience can be traced back to the touchpoints with whom the customer gets in contact with, notably the people involved in handling, manufacturing and distributing the products. It gives a kind of "service character" to it all. Indeed, most of the examples cited by the literature are services. Nevertheless, customer experience is the key to success in the case of tangible goods as well. In fact, we are witnessing a kind of paradigm shift here also. We must agree with Kenesei and Kolos (2018) who said that the new paradigm, the "service-dominant logic" (SDL) described by Vargo and Lusch (2004) should be understood in such a way that the tools of service marketing are to be introduced into the world of physical products. So perhaps one of the most critical tools in services marketing and in customer experience are the appropriate people.

Customer experience is created as a result of the satisfaction of the buyer with the so-called touchpoints of the supplier. Some of these touchpoints are of a personal nature. It is an obvious objective of managers to make customers satisfied with the behavior of the company's employers, particularly front-line people easy to achieve.

This is where human resource management (HRM) comes into play. People with emotional intelligence should be hired for these positions and should be trained and empowered for these tasks, who possess the appropriate attitude towards the customers (Boxer and Rekettye, 2010). It is not easy to realize the vision of the management by the people working in the front lines. With mentioning the touchpoints, we arrived to the changing concept of the consumer decision journey.

\section{Consumer Decision Journey}

Traditional marketing has taught us that consumers take a particular journey before making their purchase decisions. This journey was illustrated with a funnel metaphor, where the number of potential brands gradually decreases. As Kotler and Keller describe in their 'five-stage model' (Kotler and Keller, 2006, p. 191), it starts with the problem recognition, followed by the information search, evaluation of alternatives, and decision. The decision means the purchasing of the product, followed by the post-purchase behavior of the customer, which can ideally manifest itself in loyalty, or even in evangelism.

Representing the decision journey of consumers as a funnel implies that the initial list of brands considered worthy of attention by the consumers (initial consideration list) is gradually narrowed down in each step until only one remains at the point of purchase. Companies, through their marketing activities at the touchpoints, try to "push" their own brands down the funnel.

The research conducted by Court et al. (2009) found that something different was happening on the decision journey in today's digital world. For example, due to (or despite) the proliferation trend of products and media, the initial consideration list has become narrower than before; and the whole decision-making process can be described more like a circular movement, in which the initial consideration list is followed by the active evaluation phase. In this phase, brands can be subtracted from or new brands can be added to the list. It is followed by the closing, the purchase itself, and then the post-purchase phase. During this last phase the consumer gains 
experiences by using the product, he/she evaluates it and ideally enters the so-called loyalty loop.

The research has provided several important findings:

- Contrary to the funnel model, the initial consideration list most of the times does not get narrowed down in the active evaluation phase, moreover it gets expanded as a result of an intensive search for information. For example, the initial consideration list in the case of cars was typically 3.8 to which was added a further 2.2 during the intensive information search.

- The second important finding is that the touchpoints of the active evaluation phase were not dominated by the marketing activities of the suppliers, but rather by the customer-driven (.,pull") activity, particularly by online reviews, recommendations by friends and family members, as well as the interactions experienced in the shops. Traditional, supplier-driven marketing has a more important role in the creation of the initial consideration list, but its importance diminishes during the phases of active evaluation and final decision.

- The final decision is principally influenced by two factors: the personal interaction of the shop, the dealers and the agents, and the customer-driven marketing (word of mouth advertising, online search, offline search).

- The research has also revealed that there are two kinds of loyalty. Some of the customers are what we call active loyalists, who not only keep buying the same brand, but they also recommend it to others. The passive loyalists on the other hand are stuck with the same brand for convenience's sake or from fear of the misleading variety of choices of brands even though they might not be all too fond of their choices.

\section{Personalization of Customer Experience - Some Ethical Considerations}

One of the most important group of factors influencing customer experience is knitted to sellers. Their communication towards their customers and other activities at the different touchpoints have a great effect on the consumers purchasing decisions. The researches mentioned earlier proved that the impact of sellers' activity at these touchpoints could be more successful if they are well targeted or even personalized. In the Acquia research, for example, $78 \%$ of the consumers said that they would be more loyal to a brand that showed they really understood them and what they were looking for. How customers see the ways they can be treated individually is presented in Figure 1. 
Figure 1

Ways Brands Can Make Customers Feel Like an Individual

\begin{tabular}{|l|l|l}
\hline Ways Brands Can Make Customers Feel Like An Individual $\begin{array}{l}: \\
:\end{array}: \begin{array}{l}\text { marketing } \\
\text { charts }\end{array}$ \\
\hline & $43 \%$ & $\begin{array}{l}\text { Sends me special offers only available to me } \\
\text { Knows I am the same customer across all touchpoints } \\
\text { (e.g., in-store, email, mobile, social media, call center, etc.) } \\
\text { Enables me to customize and control how, when, where, } \\
\text { and why the brand will interact with me }\end{array}$ \\
\hline & $42 \%$ & $\begin{array}{l}\text { Sends me recommendations based on products I recently } \\
\text { purchased or viewed }\end{array}$ \\
\hline & $38 \%$ & $\begin{array}{l}\text { Sends me reminders to purchase items I left in an online } \\
\text { shopping cart that I haven't yet bought }\end{array}$ \\
\hline $1 \%$ & Other \\
\hline $11 \%$ & None \\
\hline
\end{tabular}

Published on MarketingCharts.com in April 2019 | Data Source: RedPoint Global

Based on a survey of 3,002 adults (18+) in the US (1,500), Canada (501) and UK (1,001), all of whom had purchased an item or used a service from any of the following in the previous year: physical retail store, online retail store website or app, physical bank branch, online banking website or app, or travel/tourism website or app. Source: Marketing Charts (2019)

The technology for making the company's communication with existing customers and with prospects personalized is available. It is enough to mention the huge progression in the analytics of big data, the Al (artificial intelligence), the cloud computing, etc. One would think that the new technology should make the online experience with brands better. However, according to the Acquia survey, the truth is not so cut and dry. Even though marketers have invested a lot in marketing technology and want to continue it, 74 percent of them feel that technology has made it more difficult to deliver personalized experience for the customers.

Talking about the use of personalized information one barrier and one contradiction must be mentioned. The barrier is the need to ensure to meet the data compliance standards, like GDPR. The contradiction is that however consumers prefer to get personalized treatment from the companies they do not like to give up their privacy. This contradiction is illustrated in Figure 2.

Therefore, they hesitate to give their permission to use their personal data unless they see its direct benefit.

Figure 2

The Contradiction between Customers' Expectations and Their Readiness to Give Access to Their Private Information

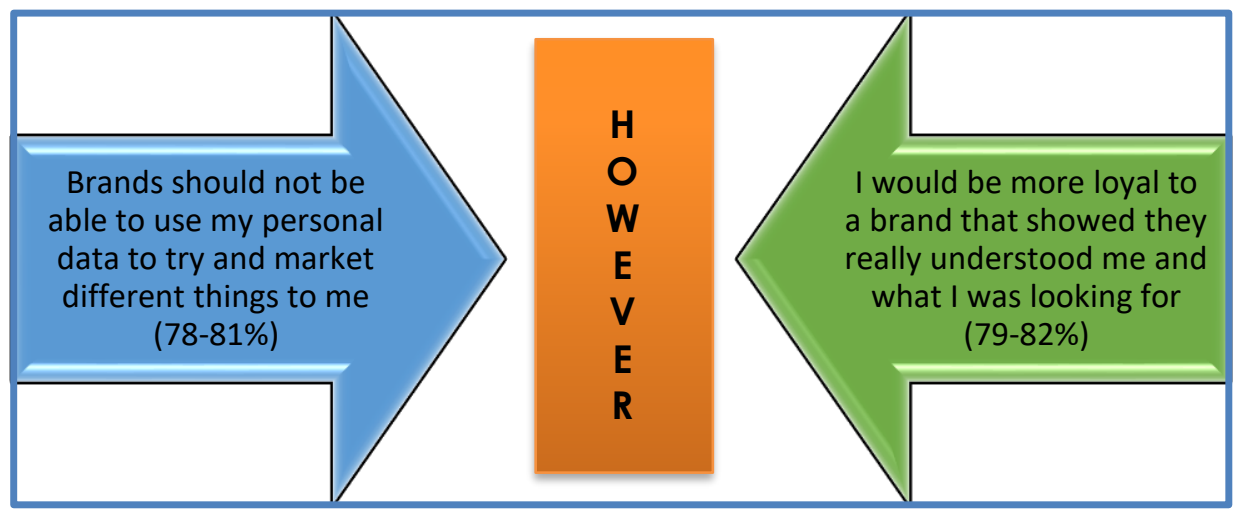

Source: Based on Acquia (2018) research 
So, companies need to find ways to convince customers that giving permission to use their IDs is worthy and beneficial to them. Let us take the example of the Turkish loyalty programme called Hopi. Hopi creates value for its customers and member merchants. Hopi personalises its merchants' campaigns by taking advantage of big data and artificial intelligence. The special artificial intelligence software behind Hopi matches the needs and expectations of its customers with the thousands of offers of its member merchants in the most appropriate way. Thus, Hopi's customers can follow and benefit from the most attractive campaigns and offers that fit their preferences and habits. Currently, $70 \%$ of Hopi customers voluntarily share their location information with Hopi (Yetkin, 2019).

\section{Conclusions}

The study has proved that in the era of Industry 4.0 providing personalized customer experience is gaining in importance. Companies need to deal with it otherwise they will lose their competitiveness.

The underlying literature review of the study showed that the marketing institutions of the advanced countries have made quite a few researches, and the companies here pay an ever-growing attention to this issue. The CEE region however is lagging behind it both in research and in practice.

The practical implications of the study can be summarized as follows: To be successful in this field companies must be present at the touchpoints generated by the customers. To achieve this, all the touchpoints for each product must be known, and the active loyalists must be continuously provided with appropriate content. It is important to ensure that customers, consumers are not to be disappointed at the personal touchpoints. Its increases the importance of human resource management. One of the priorities is to understand the customer decision journey and make sure that the product is included in the initial consideration list, and after that to provide the potential customers with appropriate and personalized information during the active evaluation phase. Finally, by identifying the appropriate touchpoints, the company should ensure that the customers' post-purchase experience is positive as well and they immediately enter into the loyalty loop during the repurchase.

The limitation of the study lies in the fact that it was not supported by field research. This will be the forthcoming task to make field research among the companies of the CEE region and to compare their results with researches made in the advanced countries.

\section{References}

1. Acquia (2018), Closing the Gap: Customer Experience Trends Report 2019, available at: https://www.acquia.com/resources/ebooks/closing-cx-gap-customer-experiencetrends-report (13 April 2019).

2. Baur, C., Wee, D. (2015) "Manufacturing's next act", McKinsey Quarterly.

3. Boxer, I., Rekettye, G. (2010), "The influence of perceived emotional intelligence on the perceived service value and customer loyalty", Acta Oeconomica, Vol. 60, No. 3, pp. 275-293.

4. Court, D., Elzinga, D., Mulder, S., Vetvik O. J. (2009), "The consumer decision journey", McKinsey Quarterly.

5. Geissbauer, R., Vedsø, J., Schrauf, S. (2016) "A Strategist's Guide to Industry 4.0", Strategy + Business, Vol. 83.

6. Kenesei, Z., Kolos, K. (2018), "Szolgáltatásmarketing - múlt vagy jövő?" (Services marketing - past or future?), Budapest Management Review, Vol 49, No. 1, pp. 2-12.

7. Kotler, P., Keller, K. L. (2006), Marketing Management, Pearson.

8. Lemon, K. N., Verhoef, P. C. (2016), "Understanding Customer Experience throughout the Customer Journey", Journal of Marketing, Vol. 80, No. 6, pp. 69-96. 
9. Liao, Y., Deschamps, F., de Freitas Rocha Loures, E., Pierin Ramos, L. F. (2017), "Past, present and future of Industry 4.0 - a systematic literature review and research agenda proposal", International Journal of Production Research, Vol. 55, No. 12, pp. 3609-3629.

10. Marketing Charts (2019), "How Can Brands Make Customers Feel Like Individuals?", available at: https://www.marketingcharts.com/customer-centric/personalizationcustomer-centric-108074? mc cid=cd4255ca44\&mc_eid=3085ef12e5 (13 April 2019).

11. Moavenzadeh, J. (2015), "The 4th Industrial Revolution: Reshaping the Future of Production", World Economic Forum.

12. NICE in Contact (2018), "2018 Customer Experience (CX) Transformation Benchmark", available at: https://www.niceincontact.com/call-center-resource-finder/2018-cxtransformation-benchmark-study (13 April 2019).

13. Rekettye, G. (2018), Értékteremtés 4.0 (Value Creation 4.0), Akadémiai Kiadó, Budapest.

14. Rekettye, G., Rekettye Jr., G. (2019), "The effects of the digital revolution on costs and prices", in Drezgić, S., Žiković, S., Tomljanović, M. (Eds.), Economics of Digital Transformation, University of Rijeka, Faculty of Economics and Business, pp. 131-145.

15. Richardson, A. (2010), "Understanding Customer Experience", Harvard Business Review.

16. Salesforce research (2018), "State of the Connected Customers - Insights from 6700+ consumers and business buyers on the intersection of experience, technology, and trust", available at:

https://www.salesforce.com/content/dam/web/en_us/www/documents/ebooks/state-of-the-connected-customer-report-second-edition2018.pdf (13 April 2019).

17. Schwab, K. (2017), The Fourth Industrial Revolution, Penguin Random House, New York.

18. Vaidya, S., Ambad, P., Bhosle, S. (2018), "Industry 4.0 - A Glimpse", Procedia Manufacturing, Vol. 20, pp. 233-238.

19. Vargo, S. L., Lusch, R. F. (2004), "Evolving to a new dominant logic for marketing", Journal of Marketing, Vol. 68, pp. 1-17.

20. Yetkin, A. M. (2019), "How Can a Loyalty Programme Deliver Value to Customers? The Case of Hopi", in Rekettye, G. (Ed.), Value Creation 4.0, Transnational Press London (under publication).

\section{About the authors}

Gábor Rekettye is a Professor Emeritus at the University of Pécs and Honorary Professor at the University of Szeged. He received his Master degree from Budapest University of Economics, and his PhD degree from the Hungarian Academy of Sciences, both in Economics. He is the author of several textbooks, which are taught at different universities in Hungary. In addition, he has written around 300 publications in Hungary and abroad. In his carrier, he was working in the industry, in foreign trade, and for five years, he has served as the Commercial Counsellor of Hungary in Tokyo, Japan. Between 1993 and 1996, he was the Dean of the Business School. In 2003, he received the highest scientific title in Hungary, 'The Doctor of the Hungarian Academy of Sciences'. The author can be contacted at rekettye.gabor@ktk.pte.hu.

Gábor Rekettye, Jr. is an Associate Professor at the International Business School (IBS) Budapest. He received his Master's in Marketing Management from Middlesex University, London, UK. He made his PhD at the Széchenyi István University, Győr in 2016. His teaching career began at the Faculty of Business and Economics of the University of Pécs. Currently he teaches marketing, marketing communication and international marketing for the international students of IBS. His field of research is also connected to marketing communication and international marketing. He has published a few studies both in domestic and international journals. The author can be contacted at gabor.r@gmail.com. 